\title{
Characterization of Antibacterial Activity of Selected Essential Oils
}

\author{
Sujata Hota and Chandi C. Rath* \\ P. G. Department of Life Sciences, Rama Devi Women's University, \\ Vidya Vihar, Bhubaneswar-751022, India \\ *Corresponding author
}

\section{A B S T R A C T}

Keywords

Escherichia coli,

Staphylococcus

aureus,

Pseudomonas

aeruginosa,

Essential oils,

Minimum Inhibitory

Concentration (MIC)

Minimum Killing

Time (MKT)

Multiple Antibiotic

Resistance (MAR)

Article Info

Accepted:

14 August 2019

Available Online:

10 September 2019
In the present investigation, eleven essential oils (Curry Leaf, Ginger, Azowan, Betel leaf, Black cumin, Marjoram, Hedychium, Calamus, Peppermint, Cinnamon, Basil) were screened, in order to assess their antimicrobial activities against three bacteria (Escherichia coli, Staphylococcus aureus and Pseudomonas aeruginosa). Of the eleven essential oils studied, Azowan, Peppermint, Basil, Black cumin and Cinnamon oils showed strong antibacterial activity against the pathogens. The Minimum inhibitory concentration (MIC) values of the oils, ranged between $0.48-125 \mu \mathrm{l} / \mathrm{ml}$. The Minimum Killing Time (MKT) of the oils varied from 0 to 60 mins, at room temperature. The oils retained their antibacterial activities, even after heat treatment $\left(100^{\circ} \mathrm{C}\right.$ for one hour), and on autoclaving which indicated the presence of barostable and thermostable components in these oils. The phenol co-efficient values of the oils fall between $0.25-0.5$. The antibiotic sensitivity pattern of the pathogens had shown multiple antibiotic resistance (MAR). The activities of the oils reported to be bactericidal in nature, and were well compared to the standard antibacterial compounds.

\section{Introduction}

Many bacterial and fungal pathogens have evolved numerous defense mechanisms against antimicrobial agents and showed resistance to old and newly produced drugs. For the last few decades, multi drug resistance has become an increasing concern for both gram positive and gram negative bacteria (Brunel and Guery, 2017). The resistance of the microorganisms increased due to over and misuse of the commercial antimicrobial drugs and chemotherapeutic agents as well as a lack of new drug development by the pharmaceutical industry (Gould and Bal, 2013; Viswanathan, 2014; Michael et al., 2014).

This situation has forced the researchers and academicians, to search for new antimicrobial substances from various sources, foremost are the medicinal and aromatic plants, as plant 
products are biodegradable, and without any side effects to the animals and environment.

Several aromatic and medicinal plants produce essential oils (EOs). EOs are hydrophobic liquid, clear or unusually coloured, composed of complex compounds that are volatile in nature. They are characterised by strong odour and obtained from medicinal and aromatic plants part such as flowers, leaves, seeds, bark, fruits and roots (Burt, 2004). EOs have been reported to possess antifungal, antibacterial, antiviral, antioxidant, analgesic and anti- inflammatory activities (Gao et al., 2011; Gilles et al., 2010; Kordali et al., 2005; Mourey \& Canillac, 2002; Prakash et al., 2011). There is an dire need for newer antimicrobial compounds, and EOs are less studied. So, this prompted us to test the antibacterial activity of some selected essential oils against the bacterial pathogens such as E.coli, S. aureus and P. aeruginosa.

\section{Materials and Methods}

\section{Pathogens}

The test pathogens [Escherichia coli (MTCC1675), Staphylococcus aureus (MTCC-902), and Pseudomonas aeruginosa (MTCC-741)] were used in this study and were obtained from P.G Department of Microbiology, College of Basic Science and Humanities, OUAT, Bhubaneswar.

\section{Essential oils}

Eleven different EOs viz., Curry Leaf (Murraya koenigii), Azowan (Trachyspermum ammi), Betel leaf (Piper betel), Black cumin (Nigella sativa), Peppermint (Mentha piperita) from Southern species, Madurai, Ginger (Zingiber officinales), Marjoram (Origanum marjorana), Hedychium (Hedychium coronarium), Calamus (Acorus calamus) from Hitesh Aromatics, Mandi, Himachal Pradesh, and Cinnamon (Cinnamomum verum), Basil (Ocimum basilicum) were procured from Flower and Fragrance development cooperation, Berhampur, Odisha, were used to assess their antimicrobial activities against the test pathogens.

\section{Media and Chemicals}

Nutrient broth (NB), Nutrient agar (NA) and Tween 80 were procured from Hi-Media Ltd. Mumbai, India, and all the media were prepared according to manufacturer's instruction. The media were supplemented with $0.75 \%$ of Tween 80 (T-80) to facilitate the miscibility of the oils.

\section{Preliminary screening of oils by Disc Diffusion Method (DDM)}

For the preliminary screening of the EOs, Disc Diffusion Method (DDM) described by Bauer et al., (1996) was used, to assess their antimicrobial properties qualitatively.

\section{Determination of the Minimum Inhibitory concentration (MIC) of the oils}

Minimum Inhibitory Concentration of the oils was determined by Tube Dilution Method described by Rath et al., (1999), with slight modification. In brief, NB was supplemented with $0.75 \%$ Tween 80 and was dispensed into test tubes and sterilized. By the help of sterile pipette, $0.5 \mathrm{ml}$ of the oil was transferred to the first test tube and mixed by vortexing for a homogenous emulsion. Further, the sample was serially diluted as two- fold dilution. From the $10^{\text {th }}$ test tube, $0.5 \mathrm{ml}$ of emulsion was discarded. $20 \mu \mathrm{l}$ of freshly grown culture was added to all test tubes, and incubated at $37^{\circ} \mathrm{C}$ for $24 \mathrm{hrs}$. One tube without oil served as control. A loop full of bacterial culture was taken from each test tube, and then streaked on the agar plates. Plates were incubated at $37^{\circ} \mathrm{C}$ for $24 \mathrm{hrs}$. After the incubation period, 
the plates were observed for the bacterial growth. No growth of the test organism at a particular concentration was determined as MIC for that oil.

\section{Determination of the Minimum Killing Time (MKT) of the oils}

The Minimum Killing Time (MKT) of the oil was described by Rath et al., (2005). Overnight incubated NB cultures of microorganisms were inoculated into NB containing MIC level of the oils, and were incubated at $37^{\circ} \mathrm{C}$. One tube without oil served as Control. Under aseptic conditions, one loop full of the sample from the test tubes was sub cultured on to NA plates at $0^{\prime}, 2^{\prime}, 5^{\prime}, 10^{\prime}, 15^{\prime}$, $30^{\prime}, 1 \mathrm{hr}, 2 \mathrm{hrs}$, 3hrs, $4 \mathrm{hrs}$ and $5 \mathrm{hrs}$ of interval and incubated at $37^{\circ} \mathrm{C}$ for $24 \mathrm{hrs}$. After incubation, the plates were observed for bacterial growth. No growth on sub-culturing at the particular time, was regarded as the minimum time required to kill the bacteria by that oil.

\section{Effect of temperature and pressure on antibacterial activity of oils}

An experiment was designed to study the effect of high temperature (by treating the oils at $100^{\circ} \mathrm{C}$ for $1 \mathrm{hr}$, in a boiling water bath) and pressure (autoclaving the oils) on antibacterial activity of the test oils by Disc Diffusion Method. Sterile filter paper discs were mounted on the surface of the pre-cultured (from 24hrs old culture, swept on NA plates) bacterial pathogens on agar plates at equal distance. Subsequently, all the EOs were heated at $100^{\circ} \mathrm{C}$ for $1 \mathrm{hr}$ and autoclaved at $121^{\circ} \mathrm{C}$ and $15 \mathrm{lbs}$ pressure, for 20 mins.

Using a sterile pipette, EOs were loaded (at MIC level) over the sterile filter paper discs separately, and incubated at $37^{\circ} \mathrm{C}$ for $24 \mathrm{hrs}$. Plates were observed for zone of clearance around the discs which indicates positive antibacterial activity of the treated oils, in comparison to control oil.

Determination of the Phenol Coefficient value of the oils

Selective oils that had shown better antibacterial properties, were subjected to phenol coefficient test, in order to compare their efficiency, described by Rath and Mohapatra (2015).

\section{Determination of drug sensitivity pattern of test pathogens}

An experiment was conducted, to study the antibiogram as well as the multiple antibiotic resistances (MAR \%) pattern of the test pathogens, in order to compare the antibacterial activity of the EOs with standard antibacterial drugs. The antibiogram pattern was studied following the method of Bauer et al., (1996). Standard antibiotic discs, procured from Hi-Media, Mumbai were used in this study. After the incubation period, plates were observed for susceptibility (sensitivity of the organism to an antibiotic) or resistance (no zone of clearance around the disc) of the pathogen towards a specific antibiotic. The multiple antibiotic resistance $\%$ of the pathogens was determined by using the formula:

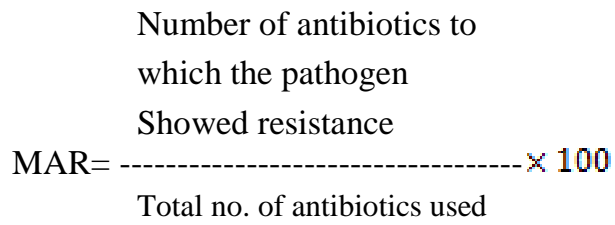

\section{Results and Discussion}

The bioactivities of eleven EOs were evaluated against three pathogens (E.coli, $S$. aureus and $P$. aeruginosa). The EOs of Azowan, Peppermint, Basil, Black cumin and Cinnamon had shown strong antibacterial activity, in terms of their zone sizes against 
the test pathogens (Table-1). The Zone of Inhibition ranged from 8-32 $\mathrm{mm}$. Azowan oil had shown similar results against E.coli and $S$. aureus $(25 \mathrm{~mm})$, respectively whereas, showed zone size of $30 \mathrm{~mm}$ against $P$. aeruginosa. The three test organisms were resistant to Curry leaf oil. Resistance was too observed in case of E.coli and S. aureus against betel leaf and Calamus oil. The oils differ in their antibacterial activities against the test pathogens, in terms of Zone of inhibition. In comparison to our observations, Mekonnen et al., (2016) also reported that, Trachyspermum schimperi had shown higher zone sizes of $23.5 \mathrm{~mm}, 12 \mathrm{~mm}$ and $16 \mathrm{~mm}$ against $S$. aureus, E.coli, and $P$. aeruginosa, respectively.

Minimum Inhibitory Concentration (MIC) values of four oils (Betel leaf, Cinnamon, Marjoram and Peppermint) evaluated against three test pathogens, ranged from 0.48-125 $\mu \mathrm{l} / \mathrm{ml}$ (Table-2). Lowest MIC values of 0.97 $\mu \mathrm{l} / \mathrm{ml}$ and $0.48 \mu \mathrm{l} / \mathrm{ml}$ were observed in case of Cinnamon oil against E.coli and S. aureus, respectively.

Highest MIC value of $125 \mu \mathrm{l} / \mathrm{ml}$ was observed in case of peppermint against $S$. aureus. Oils of Betel leaf and Marjoram had shown MIC value of $62.5 \mu \mathrm{l} / \mathrm{ml}$ against $S$. aureus and $P$. aeruginosa, respectively, whereas Cinnamon oil showed similar MIC value of $62.5 \mu \mathrm{l} / \mathrm{ml}$ against $P$. aeruginosa. In comparison to our observations, Lv et al., (2011) also reported lower MIC value (0.1-0.4 $\mu \mathrm{l} / \mathrm{ml})$ of Cinnamon oil against $S$. aureus and E.coli. Generally, higher MIC values observed against Gm-ve bacteria in comparison to Gram+ve bacteria could be attributable to the thick layer of lipopolysaccharide (more resistant to EOs) outer membrane covering the cell wall as compared with the gram-positive bacteria having homogenous peptidoglycan layer structure (Salton, 1953; Sikkema, D et al., 1995; Hsouna et al., 2011). In contrast, in our studies, we observed higher MIC values of EOs against $S$. aureus as compared to E.coli. The activities of the EOs were observed to be bactericidal, as no growth was recorded on subculture onto NA plates from the MIC dilution tubes. The Minimum Killing Time (MKT) of the oils, varied from 0 to 60 mins, at room temperature (Table-3). Oils of Betel leaf killed both the pathogens (E.coli and $S$. aureus) within 30 mins. Peppermint oil killed E.coli and $P$. aeruginosa within 60 mins.

The oils of Marjoram and Cinnamon killed all the three test pathogens within 0 min. Killing of these pathogens immediately by these EOs suggested that the oils cause an irreversible damage to the cellular structure of the pathogens, when they come in contact with the oil mixture (Pattnaik et al., 1995; Rath et al., 1999a, b, 2001, 2002 \& 2005).

The tested oils had shown antibacterial activity even after treating them at $100^{\circ} \mathrm{C}$ for an hour (in a boiling water bath), and autoclaving $\left(121^{\circ} \mathrm{C}\right.$ and $15 \mathrm{lb}$ pressure for 20 mins) (Table-4).

In case of Marjoram and Peppermint oil, zone size was highly decreased, when treated with high pressure and temperature as compared to normal untreated oil, against E.coli and $S$. aureus. Betel leaf and Cinnamon oil when treated with high temperature, the zone of inhibition was same as that of untreated oil against E.coli and S. aureus, respectively. All the oils had shown decrease in the zone size by boiling and autoclaving, against $P$. aeruginosa, but the changes were not remarkable. Observation of antibacterial activity of the tested EOs even on heat treatment and autoclaving, indicated the presence of some thermostable and barostable components in the oils. Rath et al., (2001) observed decreased activity of turmeric leaf and rhizome essential oils, against these pathogens. 
Table.1 Antimicrobial activities of essential oils by using Disc Diffusion Method

\begin{tabular}{|l|l|c|c|c|}
\hline Sl. no. & Essential Oils & \multicolumn{3}{|c|}{ Zone of Inhibition (ZOI) in mm. } \\
\hline & & E.coli & S. aureus & P. aeruginosa \\
\hline $\mathbf{1 .}$ & Curry leaf & $\mathrm{R}$ & $\mathrm{R}$ & $\mathrm{R}$ \\
\hline $\mathbf{2 .}$ & Ginger & 12 & 11 & 20 \\
\hline $\mathbf{3 .}$ & Azowan & 25 & 25 & 30 \\
\hline $\mathbf{4 .}$ & Betel leaf & $\mathrm{R}$ & $\mathrm{R}$ & 20 \\
\hline $\mathbf{5 .}$ & Black cumin & 12 & 20 & 32 \\
\hline $\mathbf{6 .}$ & Marjoram & 10 & 14 & 10 \\
\hline $\mathbf{7 .}$ & Hedychium & 8 & $\mathrm{R}$ & 14 \\
\hline $\mathbf{8 .}$ & Calamus & $\mathrm{R}$ & $\mathrm{R}$ & 10 \\
\hline $\mathbf{9 .}$ & Peppermint & 11 & 10 & 25 \\
\hline $\mathbf{1 0 .}$ & Basil & 24 & 18 & 23 \\
\hline $\mathbf{1 1 .}$ & Cinnamon & 24 & 10 & 20 \\
\hline
\end{tabular}

*R- Resistant

Table.2 Minimum Inhibitory Concentration (MIC) of oils

\begin{tabular}{|l|l|l|l|l|}
\hline Sl.no. & Essential Oils & \multicolumn{3}{|l|}{ MIC VALUES $(\boldsymbol{\mu l} / \mathbf{m l})$} \\
\hline 1. & & Escherichia coli & $\begin{array}{l}\text { Staphylococcus } \\
\text { aureus }\end{array}$ & $\begin{array}{l}\text { Pseudomonas } \\
\text { aeruginosa }\end{array}$ \\
\hline 2. & Betel leaf & 7.81 & 62.5 & 62.5 \\
\hline 3. & Marjoram & 0.97 & 0.48 & 62.5 \\
\hline 4. & Peppermint & 31.25 & 62.5 & 62.5 \\
\hline
\end{tabular}

* $\mathbf{R}=$ Resistant to particular oil

Table.3 Minimum Killing Time of essential oils against test pathogens

\begin{tabular}{|l|l|c|c|c|}
\hline Sl.no. & Essential Oils & \multicolumn{3}{|c|}{ MINIMUM KILLING TIME (MKT) AT 37॰C IN MINS } \\
\hline & & Escherichia coli & $\begin{array}{l}\text { Staphylococcus } \\
\text { aureus }\end{array}$ & $\begin{array}{l}\text { Pseudomonas } \\
\text { aeruginosa }\end{array}$ \\
\hline 1. & Betel leaf & $30 \mathrm{mins}$ & $30 \mathrm{mins}$ & $0 \mathrm{~min}$ \\
\hline $\mathbf{2 .}$ & Cinnamon & $0 \mathrm{~min}$ & $0 \mathrm{~min}$ & $0 \mathrm{~min}$ \\
\hline $\mathbf{3 .}$ & Marjoram & $0 \mathrm{mins}$ & $0 \mathrm{~min}$ & $0 \mathrm{~min}$ \\
\hline 4. & Peppermint & 60mins & 0min & $60 \mathrm{mins}$ \\
\hline
\end{tabular}


Table.4 The effect of temperature and pressure on antibacterial activities of the oils

\begin{tabular}{|c|c|c|c|c|c|c|c|c|c|}
\hline \multirow{3}{*}{$\begin{array}{l}\text { Essential } \\
\text { oils }\end{array}$} & \multicolumn{9}{|c|}{ Zones of Inhibition (in $\mathrm{mm}$ ) at different temperatures } \\
\hline & \multicolumn{3}{|c|}{ E.coli } & \multicolumn{3}{|c|}{ S. aureus } & \multicolumn{3}{|c|}{ P. aeruginosa } \\
\hline & UT & $100^{\circ} \mathrm{C}$ & $\mathbf{A}$ & UT & $100^{\circ} \mathrm{C}$ & $\mathbf{A}$ & $\mathbf{U T}$ & $100^{\circ} \mathrm{C}$ & $\mathbf{A}$ \\
\hline Betel leaf & 15 & 15 & 14 & 12 & 14 & 12 & 12 & 2 & 9 \\
\hline Cinnamon & 14 & 15 & 13 & 13 & 13 & 14 & 10 & 9 & 10 \\
\hline Marjoram & 13 & 7 & 8 & 11 & 10 & 9 & 10 & 10 & 9 \\
\hline Peppermint & 11 & 8 & 9 & 18 & 17 & 16 & 7 & 9 & $\mathrm{R}$ \\
\hline
\end{tabular}

UT- Untreated i. e oils were tested without heating or autoclaving, A: autoclaved oils, oils were applied at MIC level on discs.

Table.5 Phenol Co-efficient value of essential oils

\begin{tabular}{|l|l|}
\hline Essential oils & Phenol coefficient \\
\hline Betel leaf & 0.25 \\
\hline Marjoram & 0.5 \\
\hline Peppermint & 0.5 \\
\hline Cinnamon & 0.25 \\
\hline
\end{tabular}

Table.6 Antibiogram pattern of the test pathogens tested by DDM of Bauer et al., (1996)

\begin{tabular}{|l|l|c|l|}
\hline \multirow{2}{*}{ PATHOGENS } & \multicolumn{3}{|c|}{ ANTIBIOGRAM } \\
\cline { 2 - 4 } & Sensitive to & Resistant to & MAR\% \\
\hline Escherichia coli & $\begin{array}{l}\mathrm{Co}(18), \mathrm{Cq}(13), \mathrm{GEN}(18), \\
\mathrm{AK}(19), \mathrm{CE}(22), \mathrm{C}(31), \\
\mathrm{S}(18), \mathrm{NF}(22), \mathrm{Do}(20)\end{array}$ & $\begin{array}{c}\text { MET, AP, NS, P, } \\
\mathrm{B}, \mathrm{Lz}, \mathrm{PB}, \mathrm{Ax}\end{array}$ & $47.05 \%$ \\
\hline $\begin{array}{l}\text { Staphylococcus } \\
\text { aureus }\end{array}$ & $\mathrm{Co}(21), \mathrm{Cq}(21), \mathrm{GEN}(21)$, & $\mathrm{MET}, \mathrm{AP}, \mathrm{NS}, \mathrm{Lz}$, & $29.41 \%$ \\
& $\mathrm{AK}(21), \mathrm{CE}(16), \mathrm{C}(29)$, & $\mathrm{PB}$ \\
& $\mathrm{S}(21), \mathrm{NF}(24), \mathrm{P}(23)$, & & \\
& $\mathrm{B}(15), \mathrm{Do}(27), \mathrm{Ax}(19)$ & & \\
\hline $\begin{array}{l}\text { Pseudomonas } \\
\text { aeruginosa }\end{array}$ & $\mathrm{Cq}(13), \mathrm{GEN}(17), \mathrm{Ak}(19)$, & $\mathrm{Co}, \mathrm{MET}, \mathrm{AP}, \mathrm{NS}$, & $52.94 \%$ \\
& $\mathrm{CE}(22), \mathrm{C}(31)$, & $\mathrm{Ax}, \mathrm{P}, \mathrm{B}, \mathrm{Lz}, \mathrm{PB}$ & \\
\hline
\end{tabular}

The values in paranthes indicates zones of inhibition in $\mathrm{mm}$

They reported that the viscosity of the oil increased at higher temperature $\left(100^{\circ} \mathrm{C}\right)$ which could be an inhibiting factor in the diffusibility of the oils over the plates and results in smaller zones of inhibition. Das (2008) and Das et al., (2009) reported the antibacterial activity of EOs of three Ocimum spp. and their cocktail mixture at high temperature and pressure treatment. They observed the presence of heat stable and baro stable components in these oils, as reported in our studies. 
The phenol co-efficient value of the four oils tested, ranged from 0.25- 0.5 (Table-5). Highest phenol co-efficient value (0.5) was observed in case of Marjoram and Peppermint. Betel leaf and Cinnamon oil had shown lowest phenol co-efficient value of 0.25 . Rath et al., (2008) reported that samples with lowest MIC values had shown highest phenol coefficient values which differs from our investigation.

The antibiogram pattern of the test pathogens is presented in Table-6. From the antibiogram pattern, all the organisms were resistant to Methicillin, Amphotericin-B, Nystain, Linezolid and Polymyxin-B, whereas, the sensitivity pattern differs. The antibiotic sensitivity pattern of the pathogens showed multiple antibiotic resistance (MAR). Highest MAR \% was recorded in case of $P$. aeruginosa (52.94\%), followed by E.coli $(47.05 \%)$ and $S$. aureus $(29.41 \%)$. The zone of inhibition observed in case of the essential oils could be well compared with standard antibiotics. Smaller zone of inhibition by Eos with respect to antibiotics used, could be attributable to the crudeness of the active compound(s) present in the tested EOs.

Senhaji et al., (2007) observed the antibacterial activity of essential oil from Cinnamum zeylanicum against E.coli 0157:H7 is through outer membrane disintegration and increasing the permeability to ATP through cytoplasmic membrane that corroborates with the findings observed in this investigation as E.coli was resistant to Penicillin and Bacitracin. Similarly, Rath et al., (2005) also reported the anti-staphylococcal activity of Juniper and Lime essential oils against methicillin resistant Staphylococcus aureus (MRSA) through inhibition of cell membrane synthesis. This corroborates with our observations. Through this investigation we have placed in record, the antibacterial activity of the essential oils, is suggestive of their uses in discovery of newer antimicrobial compounds, and / or in pharmaceutical, aroma and cosmetics industries with proper scientific investigations.

\section{References}

Bauer, A. W., Kirby, W. M., Sherris, J. C., and Truck, M., 1996. America. J. Clin. Pathol. 14 (17): 493-496.

Brunel, A. S., and Guery, B., 2017. Multidrug resistant (or antimicrobial resistant) pathogens - alternatives to new antibiotics. Swiss Med Wkly. Nov 22; 147: w14553. DOI: 10.4414.

Burt, S., 2004. Essential oils: Their antibacterial properties and potential application in foods- a review. Int. J. Food microbio. 94: 223-253.

Das, I., Tayung, K., Rath, C. C., and Mohapatra, U. B., 2009. Antibacterial assessment of essential oils of three Ocimum spp. against food borne pathogens. Plant Sci. Res. 31: 60-5.

Das, I., 2008. In vitro antimicrobial potential assessment of essential oils of three Ocimum spp. M. Phil thesis, North Orissa University: $1-60$.

Gao, C. Y., Tian, C. R., Lu, Y. H., Xu, J. G., Luo, J. Y., and Guo, X. P., 2011. Essential oil composition and antimicrobial activity of Sphallerocarpus gracilis seeds against selected food-related bacteria. Food Control. 22: 517-522.

Gilles, M., Zhao, J., An, M., and Agboola, S., 2010. Chemical composition and antimicrobial properties of essential oils of three Australian Eucalyptus species. Food Chemistry. 119: 731737.

Gould, I. M., and Bal, A. M., 2013. New antibiotic agents in the pipeline and how they can overcome microbial resistance. Virulence: 4(2): 185-191.

Hsouna, A. B., Trigui, M., Mansour, R. B., Jarraya, R. M., Damak, M., and Jaoua, 
S., 2011. Chemical composition, cytotoxicity effect and antimicrobial activity of Ceratonia siliqua essential oil with preservative effects against Listeria inoculated in minced beef meat. International Journal of Food Microbiology. 148 (1): 66-72.

Kordali, S., Kotan, R., Mavi, A., Cakir, A., Ala, A., and Yildirim, A., 2005. Determination of the chemical composition and antioxidant activity of the essential oil of Artemisia dracunculus and of the antifungal and antibacterial activities of Turkish Artemisia absinthium, A. drancunculus, Artemisia santonicum, and Artemisia spicigera essential oils. Journal of Agricultural and Food Chemistry. 53: 9452-9458.

Lv, F., Liang, H., Yuan, Q., and Chunfang, Li., 2011. In vitro antimicrobial effects and mechanism of action of selected plant essential oil combinations against four food-related microorganisms. Food Research International. 44: 3057-3064.

Mekonnen, A., Yitayew, B., Tesema, A., and Tadesse, S., 2016. In vitro Antimicrobial activity of Essential oil of Thymus schimperi, Matricaria chamomilla, Eucalyptus globulus and Rosmarinus officinalis. Int. J. of Microbiology. vol. 2016, Article ID 9545693, 8 pages, doi: $10.1155 / 2016 / 9545693$.

Michael, C. A., Dominey-Howes, D., and Labbate, M., 2014. The antibiotic resistance crisis: causes, consequences, and management. Front Public Health. 2: 145 .

Mourey, A., and Canillac, N., 2002. AntiListeria monocytogenes activity of essential oils components of conifers. Food Control. 13: 289-292.

Pattnaik, S., Suvramanyam, V. R., and Rath, C. C., 1995. Effect of essential oils on the viability and morphology of Escherichia coli (SP-11). Microbios. 84: 195-9.

Prakash, B., Shukla, R., Singh, P., Mishra, P. K., Dubey, N. K., and Kharwar, R. N., 2011. Efficacy of chemically characterized Ocimum gratissimum L. essential oil as an antioxidant and a safe plant based antimicrobial against fungal and aflatoxin B1 contamination of spices. Food Research International. 44: 385-390.

Rath, C. C., Dash, S. K., Mishra, R. K. and Charuyulu, JK., 1999a. In vitro evaluation of antimycotic activity turmeric (Curcuma longa L.) essential oil against Candida albicans and Cryptococcus neoformans. Ind. Perf. 43 (4): 172-178.

Rath, C. C., Dash, S. K., Mishra, R. K., Ramachandraiah, O. S., Azeemoddin G., and Charuyulu, J. K., 1999b. A note on the characterisation of susceptibility of turmeric (Curcuma longa) leaf oil against Shigella species. Ind. Drugs. 36 (2): 133-136.

Rath, C. C., Dash, S. K. and Mishra, R. K., 2001. In vitro susceptibility of Japaneese mint leaf oil against five human fungal pathogens. Indian Perfumer: 45 (1): 57-61.

Rath, C. C., Dash, S. K., and Mishra, R. K., 2002. Antifungal efficacy of six Indian essential oils individually and in combination. J. Essent. Oil Bearing Pl. 5: 99-107.

Rath, C. C., Mishra, S., Dash, S. K. and Mishra, R. K., 2005. Antistaphylococcal activity of lime and Juniper essential oils against MRSA. Ind. Drugs. 42 (12): 797-801.

Rath, C. C., Devi, S., Dash S. K., and Mishra R. K., 2008. Antibacterial potential assessment of Jasmine essential oil against E.coli. Indian J Pharm Sci. Mar-Apr; 70(2): 238- 241. 
Rath, C. C., Mohapatra, S., 2015. Inactivation of Escherichia coli O157: Susceptibility characterisation of Candida spp. to four essential oils. Indian J. of Medical Microbiology. vol. 33(5): s93 - 96.

Salton, M. R., 1953. Studies of the bacterial cell wall: IV. The composition of the cell walls of some gram-positive and gram-negative bacteria. Biochimica et Biophysica Acta. 10(4): 512-523.

Senhaji, O., Faid, M., and Kalalou, I., 2007. H7 by essential oil from Cinnamomum zeylanicum. Braz J Infect Dis. 11: 2346.

Sikkema, J., de Bont, JA., and Poolman, B., 1995. Mechanisms of membrane toxicity of hydrocarbons. Microbiol Rev. 59 (2): 201-22.

Viswanathan, V. K., 2014. Off-label abuse of antibiotics by bacteria. Gut Microbes. 5(1): 3-4.

\section{How to cite this article:}

Sujata Hota and Chandi C. Rath 2019. Characterization of Antibacterial Activity of Selected Essential Oils. Int.J.Curr.Microbiol.App.Sci. 8(09): 1051-1059.

doi: https://doi.org/10.20546/ijcmas.2019.809.123 